\title{
Beta-adrenergic receptor blocking drugs: tear lysozyme and immunological screening for adverse reaction
}

\author{
I. A. MACKIE, D. V. SEAL, AND J. M. PESCOD \\ From Moorfields Eye Hospital and St George's Hospital, London, and Bromley College of Technology, Kent
}

SUMMARY Patients who had received long-term therapy with practolol and other beta-adrenergic receptor blocking drugs were examined ophthalmologically. Tear lysozyme concentration and serum autoantibodies (antinuclear antibodies, DNA-binding antibodies and intercellular cement substance antibodies) were measured. It was found that beta-adrenergic receptor blocking drugs may have a pharmacological effect on the lachrymal glands, but this was not associated with dry eyes or adverse reaction. Practolol was found to be capable of reducing tear lysozyme concentrations to very low levels, and this was initially associated with high titres of ICC antibody. No other drug tested produced these effects.

Beta-blocking drugs are now used extensively in the treatment of patients with ischaemic heart disease, hypertension, and cardiac dysrhythmias, and they represent a great advance in the medical treatment of these conditions. However, they have produced side effects. The cardioselective beta-adrenergic receptor blocking drug practolol has been particularly notable in this respect (Editorial, 1975). Alleged side effects have also been reported on the skin and on the eyes with other beta-blocking drugs (Cumberbatch, 1974; Padfield et al., 1975; Holt and Waddington, 1975; Knapp and Galloway, 1975; Clayden, 1975; Cubey and Taylor, 1975). However, the evidence has so far been open to doubt, and a number of alleged adverse ocular reactions have not been confirmed on further expert examination (Wright, 1975).

Ocular side effects of practolol have been described as an 'oculomucocutaneous syndrome' (OMCS), in which patients may suffer from reduced tear flow, conjunctival keratinisation, scarring, and shrinkage (Wright, 1975). A reduction of lysozyme and an absence of secretory $\operatorname{IgA}$ was found in the tear fluid of several patients. An absence of functional lachrymal gland tissue was reported in two cases of practolol OMCS which came to necropsy (Rahi et al., 1976).

Indirect immunofluorescence has shown deposition of immunoglobulin in the intercellular spaces of xenogenic squamous epithelial tissue in 27 out of 29

Address for reprints: I. A. Mackie Esq., Moorfields Eye Hospital, City Road, London ECIV 2PD cases of practolol-induced OMCS (Amos et al., 1975). High titre antinuclear antibodies were also present in 22 out of 29 cases.

Tear flow can be difficult to estimate. Schirmer's test is misleading and inaccurate (Pinschmidt, 1970; Bijsterveld, 1973). Some reports of ocular side effects to beta-blockers have been based on this test. We believe that measurement of the tear lysozyme concentration is a better guide to lachrymal gland function, and we have developed a method for its quantitative estimation (Mackie and Seal, 1976). In a preliminary study this method was used to screen the lachrymal gland function of patients on practolol (Mackie and Seal, 1975).

We report now the results of our 2-year survey of patients on practolol, with and without an adverse reaction, together with patients on tolamolol, timolol, labetalol, and propranolol. We have examined all patients' eyes, have measured their tear lysozyme concentrations, and have estimated antinuclear antibodies (ANA) and intercellular cement substance (ICC) antibodies whenever possible.

\section{Patients}

Fifty-two patients on practolol were examined, 21 of whom had typical features of the OMCS in one or both eyes. Tear fluid and serum samples were collected at the same time. Thirty-five of these patients were followed up, and serial tear and serum samples were collected. Five patients on the cardioselective beta-blocker tolamolol were similarly studied and followed up. The duration of therapy 
for each of these two groups was at least 1 year. The male to female ratio was $0 \cdot 8: 1$, and the mean age was 59 .

Seventy-two patients on three non-selective betablockers were examined on one occasion only, and tear fluid and serum samples were collected. The male to female ratio was $1 \cdot 5: 1$, and the mean age was 58.

Ten patients had taken timolol for 4 years and 13 had taken this drug for 1 year; 12 of these patients had taken low doses $(5$ to $20 \mathrm{mg} /$ day), while 11 had taken high doses ( 25 to $40 \mathrm{mg} /$ day). Sixteen patients had taken labetalol for 1 year and 10 had taken this drug for 6 months. Twentythree patients had taken propranolol for at least 1 year. The tear lysozyme concentration was also measured in 70 healthy volunteers with no ocular disease and receiving no medication. The male to female ratio was $0 \cdot 5: 1$, and the mean age was 50 .

\section{Methods}

\section{CLINICAL EXAMINATION}

This was performed after the tear fluid samples had been collected with the filter paper discs. Patients were not allowed to use any eye drops for at least 2 hours before tear samples were collected, and in particular no antibiotic drops had been used on the day of the test.

External eye examination only was performed, and visual acuities were not measured. A general view of the eye was obtained under low-power microscopy. The depth of the marginal tear strips was observed. The lower lid was everted, and the conjunctiva of the lower fornix was assessed. The upper lid was raised slightly with the finger, and a small drop of fluorescein was instilled from a sterile minim (Smith \& Nephew Ltd) so that it dropped from the conjunctiva above the superior limbus over the cornea. The tear film was then assessed for quality and break-up time. Any corneal staining or abnormality was noted. The Schirmer test was not used. The uptake of tears on the filter paper discs provided an indication of reflex tear flow. The upper lid was then everted, and the conjunctiva of the upper fornix was evaluated. It was considered that this examination was sufficient to allow the differential grouping of normal and abnormal eyes.

\section{ESTIMATION OF THE TEAR LYSOZYME} CONCENTRATION

Our original method (Mackie and Seal, 1976) was modified in order to process a larger number of specimens. Filter paper discs $5 \mathrm{~mm}$ in diameter were placed in plastic $30 \times 10 \mathrm{~mm}$ tubes and were sterilised by gamma-irradiation. The disc and tube were weighed. The disc was then placed laterally in the lower conjunctival fornix until it was saturated with tears, when it was removed and replaced in the tube. The tube containing the disc was weighed again within 2 hours, the difference in weight being equivalent to the volume of tear fluid absorbed. Filter paper discs were similarly treated with 5 different standard solutions of calibrated egg-white lysozyme (Koch-Light Ltd). Two quality control solutions were also included.

All the discs were placed on a $25-\mathrm{cm}$ square agar plate, previously flooded with Micrococcus luteus (lysodeikticus) and dried. The plate was incubated at $37^{\circ} \mathrm{C}$ for 18 hours. Zones of bacterial lysis were produced around the discs, and their diameters were measured in two directions with an image intensifier.

A linear regression line was produced from the logarithms of the different concentrations of the standard and the squared diameters of the lytic zones. This line was used to determine the concentrations of the controls and the patients' samples.

The tear lysozyme ratio was calculated for each sample. This was the ratio of the actual concentration measured to that of the lower limit of normality. This limit, which was established by our original method, varies with age. Calculation of this ratio thus allows direct comparison of all age groups.

\section{ESTIMATION OF AUTOANTIBODIES}

Antibodies to the intercellular cement substance of the baboon oesophagus were estimated by indirect immunofluorescence. All the sera were absorbed with human group A and B red blood cells before being titrated.

Antinuclear antibodies were estimated by indirect immunofluorescence using rat liver tissue. All these sera were diluted 1 in 10 . Each sample was scored from negative to strong positive $(++)$ according to the degree of fluorescent staining seen. Sera which gave a strong positive result were then titrated out. Anti-DNA antibodies were estimated by radioimmunoassay (Hughes, 1971).

The latex test was used to detect the rheumatoid factor.

\section{Results}

Results of tear lysozyme estimation are recorded as tear lysozyme ratios (right/left) on a logarithmic scale in Fig. 1. For patients from whom serial samples were collected the results shown are those measured nearest to the date on which therapy was stopped. For each group the statistical analysis is 


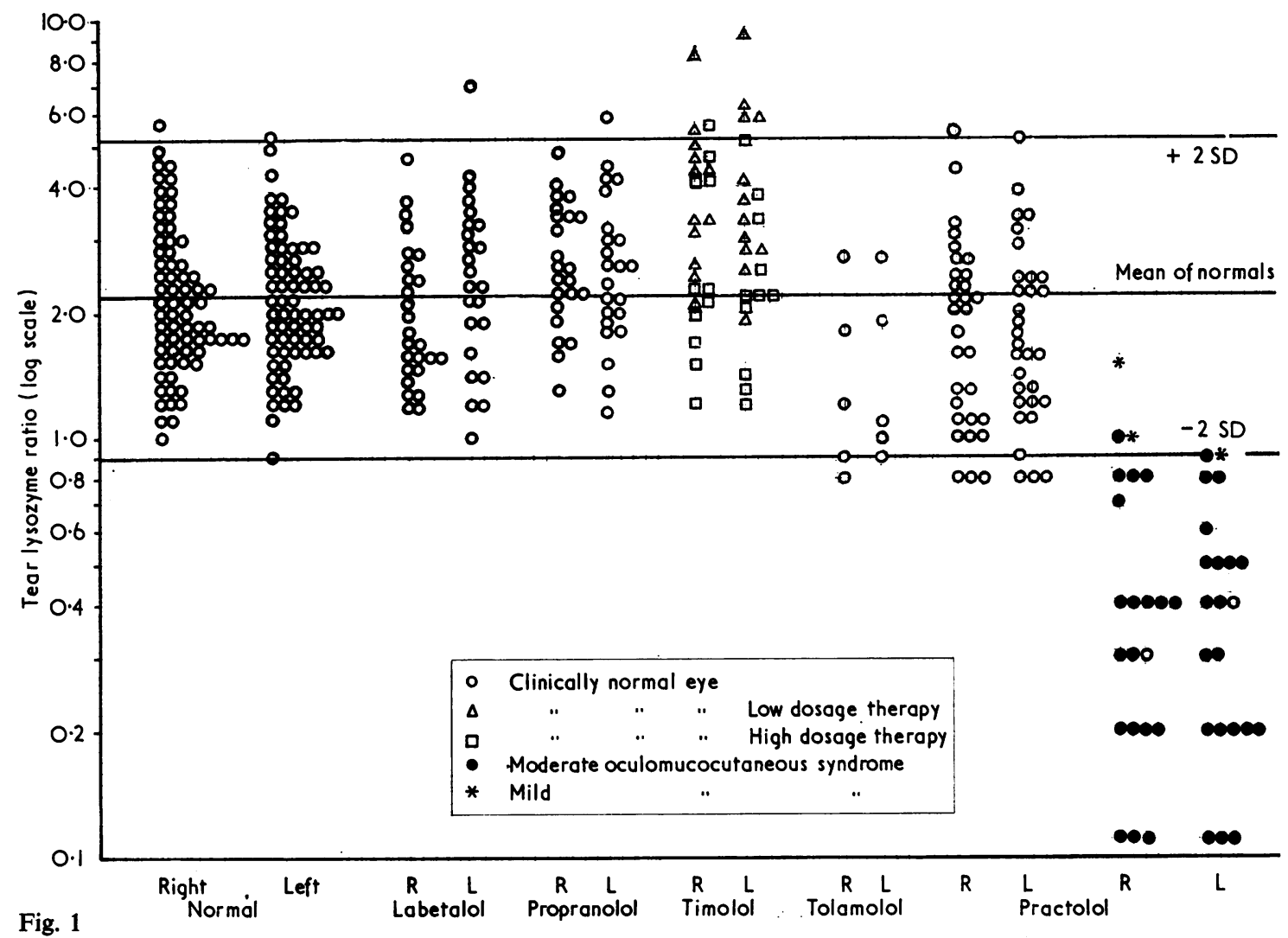

Table 1 Results of tear lysozyme ratios

\begin{tabular}{|c|c|c|c|c|}
\hline \multirow[b]{2}{*}{$\begin{array}{l}\text { Beta-blocking } \\
\text { drug }\end{array}$} & \multirow{2}{*}{$\begin{array}{l}\text { No. of } \\
\text { tear } \\
\text { samples }\end{array}$} & \multirow{2}{*}{$\begin{array}{l}\text { Geometric mean } \\
\text { tear lysozyme } \\
\text { ratio }\end{array}$} & \multicolumn{2}{|c|}{ Significance } \\
\hline & & & $\begin{array}{l}\text { Below } \\
\text { normal }\end{array}$ & $\begin{array}{l}\text { Above } \\
\text { normal }\end{array}$ \\
\hline $\begin{array}{r}\text { Practolol } \\
\text { OMCS }\end{array}$ & 42 & 0.35 & 0.001 & NS \\
\hline $\begin{array}{l}\text { clinically } \\
\text { normal eyes }\end{array}$ & 62 & $1 \cdot 75$ & 0.01 & NS \\
\hline Tolamolol & 10 & $1 \cdot 35$ & $\hat{\mathbf{v}} \cdot 01$ & NS \\
\hline $\begin{array}{l}\text { Timolol } \\
\text { low dose } \\
\text { high dose }\end{array}$ & $\begin{array}{l}24 \\
22\end{array}$ & $\begin{array}{l}3 \cdot 83 \\
2 \cdot 41\end{array}$ & $\begin{array}{l}\text { NS } \\
\text { NS }\end{array}$ & $\begin{array}{l}0.001 \\
\text { NS }\end{array}$ \\
\hline Labetalol & 50 & $2 \cdot 18$ & NS & NS \\
\hline Propranolol & 46 & $2 \cdot 46$ & NS & 0.05 \\
\hline
\end{tabular}

NS: Not significant

given in Table 1 and autoantibody results in Table 2.

The tear lysozyme ratios of the healthy volunteers followed a normal (Gaussian) distribution. The $95 \%$ confidence limits for the geometric mean value of this normal population were 2.01 to $2 \cdot 33$.
PATIENTS WITH ADVERSE OCULAR REACTION DUE TO PRACTOLOL

Patients complained of dry, gritty eyes that burned and were sore. On examination there was evidence of dryness, corneal erosions, and/or conjunctival

Table 2 Results of autoantibody screening

\begin{tabular}{|c|c|c|c|c|c|c|}
\hline \multirow{2}{*}{$\begin{array}{l}\text { Beta-blocking } \\
\text { drug } \\
\begin{array}{l}\text { Practolol } \\
\text { OMCS }\end{array}\end{array}$} & \multirow{2}{*}{$\begin{array}{l}\begin{array}{l}\text { No. of } \\
\text { serum } \\
\text { samples }\end{array} \\
20\end{array}$} & \multicolumn{3}{|c|}{$\begin{array}{l}\text { Intercellular cement } \\
\text { antibody }\end{array}$} & \multicolumn{2}{|c|}{$\begin{array}{l}\text { Antinuclear } \\
\text { antibody }\end{array}$} \\
\hline & & 0 & 0 & 16 & - & - \\
\hline $\begin{array}{l}\text { clinically } \\
\text { normal eyes }\end{array}$ & 19 & 2 & 0 & 1 & 5 & $\begin{array}{c}2 * \\
(1 / 80 \text { and } \\
1 / 160)\end{array}$ \\
\hline Tolamolol & 5 & 2 & 0 & 1 & 1 & 0 \\
\hline Timolol & 22 & 2 & 0 & 0 & 1 & 0 \\
\hline Labetalol & 16 & 0 & 0 & 0 & 1 & $\begin{array}{c}1 * \\
(1 / 160)\end{array}$ \\
\hline Propranolol & 17 & 1 & 1 & 0 & 2 & $\mathbf{0}$ \\
\hline
\end{tabular}

-Anti-DNA antibody within normal limits 
scarring. Mild and moderate cases were encountered, several with dubious scarring on initial examination, that progressed in severity over a few months.

Seven patients who had stopped practolol within the preceding 2 months were affected in both eyes. They had low right and left tear lysozyme ratios $(<0 \cdot 1$ to $0 \cdot 8 /<0 \cdot 1$ to 0.9$)$ and 6 out of 7 had high titre ICC antibody. One year later, with no evident clinical recovery, their tear lysozyme ratios were still low $(<0.2$ to $0.8 /<0.2$ to 0.8$) ; 4$ out of 6 had lost their ICC antibody.

Eleven patients who were affected in both eyes were examined on one occasion only, after they had stopped practolol. Their tear lysozyme ratios were low in both eyes ( $<0 \cdot 1$ to $1 \cdot 0 / 0 \cdot 1$ to $0 \cdot 75)$, and 7 out of 10 had high titre ICC antibody.

Two patients with normal or marginally affected
One patient stopped practolol of his own accord when he developed dry, burning eyes; he kept his eyes moist with instilled fluids for 2 months, after which he recovered from his symptoms. Clinical examination showed no signs of adverse ocular reaction, but his tear lysozyme ratios were low $(0 \cdot 4 / 0 \cdot 6)$; at that time sclerosing peritonitis also appeared. Nine months later his tear lysozyme ratios were normal $(1 \cdot 6 / 1 \cdot 4)$ and he had no ICC antibody.

\section{PATIENTS WITH NORMAL EYES ON \\ CLINICAL EXAMINATION \\ Patients on practolol}

One patient had fluctuating, low tear lysozyme ratios in both eyes, which increased to normal levels when practolol was stopped (Fig. 2b). Reflex tear flow during this period was normal and no auto-

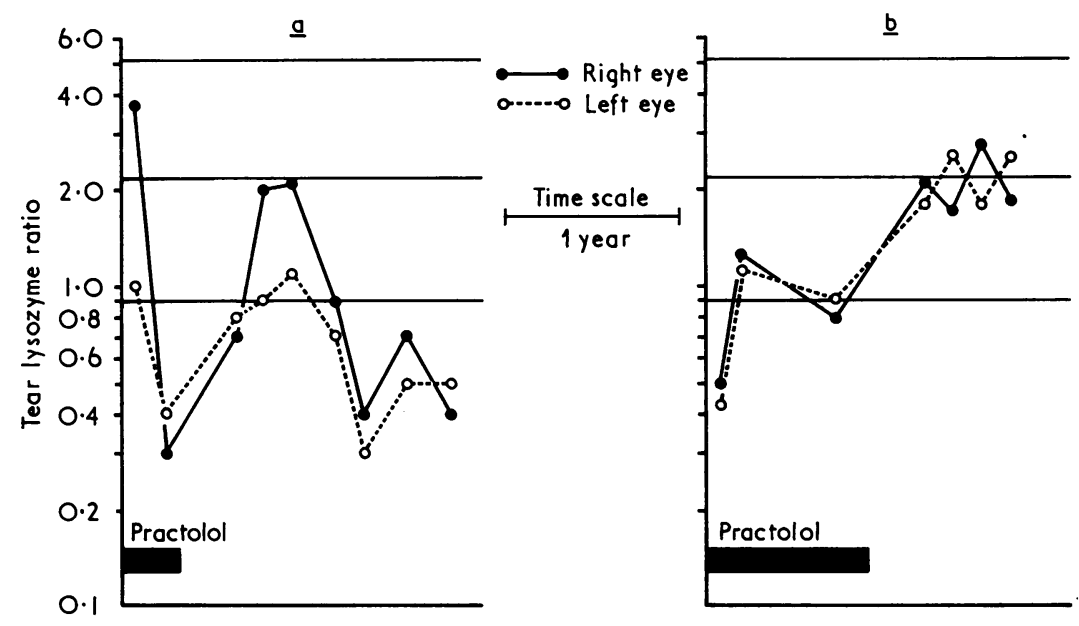

Fig. 2

right eyes had well-marked symptoms and signs in the left eyes, with low left tear lysozyme ratios $(1 \cdot 6 / 0 \cdot 5$ and $1 \cdot 5 / 0 \cdot 6)$, and both had high titre ICC antibody. One year later, with no evident clinical recovery, their left tear lysozyme ratios were still low $(1 \cdot 9 / 0 \cdot 3$ and $1 \cdot 3 / 0 \cdot 5)$; both had lost their ICC antibody.

One patient, previously described as case 17 (Mackie and Seal, 1975), had a striking fall in the tear lysozyme concentration before developing an adverse ocular reaction. After practolol was stopped the tear lysozyme ratio increased in the right eye to normal levels but has since fallen, with that of the left, to consistently low levels (Fig. 2a). The patient had initially a high titre of ICC antibody, but nine months after stopping practolol it was no longer present. The patient's clinical condition remains unchanged. antibodies were present. Two patients each had a low tear lysozyme ratio in one eye only $(1 \cdot 2 / 0 \cdot 8$ and $0 \cdot 8 / 1 \cdot 4)$. The ratios increased to normal levels $(2 \cdot 1 / 2 \cdot 1$ and $2 \cdot 7 / 3 \cdot 1)$ after practolol was stopped, and no autoantibodies were then found. Two patients had low right and left tear lysozyme ratios $(1 \cdot 0 / 0 \cdot 8$ and $0 \cdot 8 / 0 \cdot 8)$ while on practolol, but refused to be followed up.

One patient presented with a high titre of ANA but had no anti-DNA or ICC antibodies. Six months later, and 3 months after stopping practolol, the patient developed a high titre of ICC antibody; her eyes and tear lysozyme ratios were normal. Six months later sclerosing peritonitis was diagnosed at laparotomy. This indicates that practolol-induced systemic lupus erythematosus (SLE) probably preceded the practolol toxicity as evidenced by the sclerosing peritonitis. 


\section{Patients on tolamolol}

Two patients had low tear lysozyme ratios (0.9/0.9 and $0 \cdot 8 / 1 \cdot 0$ ). Since stopping the drug one has regained normal levels $(1 \cdot 1 / 1 \cdot 7)$ in the left eye, while the other patient has fluctuated in the marginal range. Neither patient developed autoantibodies.

One patient was observed to develop high titre ICC antibody but appeared clinically normal. The titre increased from 1:20 to 1:80 over a period of 4 months.

\section{Patients on timolol, labetalol, and propranolol}

The patients had normal tear lysozyme ratios except those on low doses of timolol, who had significantly increased levels. One patient on labetalol had a high titre of ANA, with a normal titre of anti-ANA antibody; this suggests that the ANA could be drug-induced.

\section{Discussion}

Patients with keratoconjunctivitis sicca have dry, irritating eyes with poor tear flow, together with reduced levels of tear lysozyme (Erickson, 1955; McEwen and Kimura, 1955). Patients with practololinduced OMCS have similar symptoms, and estimation of the concentration of their tear lysozyme has given very low values; no clinical improvement has occurred after 1 year and the tear lysozyme concentrations have remained very low.

Patients with clinically normal eyes on various doses of practolol or tolamolol had significantly reduced concentrations of tear lysozyme; several low values were found which increased to normal after therapy was stopped. Patients with clinically normal eyes on low doses of timolol had significantly increased concentrations of tear lysozyme, while those on high doses were within normal limits. There is evidence to suggest that low doses of timolol given intraveneously may produce a mild sympathomimetic effect, which is not, however, observed at high dosage (Richardson, P. J., 1976, personal communication).

The lachrymal gland is supplied by parasympathetic and sympathetic nerves, but the function of the sympathetic supply is obscure (Duke-Elder, 1968; Adler, 1970). Intravenous adrenaline has been shown experimentally in cats to stimulate tear production, but its content was not analysed (Maes, 1938). We suggest that practolol and tolamolol, $\beta_{1-}$ selective blocking drugs, may depress the secretion of tear lysozyme, while low doses of timolol may stimulate it.

Practolol-induced SLE and adverse ocular reaction are associated with high titres of ANA, as are some cases of adverse cutaneous reaction (Raftery and
Denman, 1973; Felix et al., 1974; Amos et al., 1975). Apparently unaffected patients on practolol therapy may also develop high titres (Raftery, 1974). High titres of ANA have preceded some cases of procainamide-induced SLE (Fakhro et al., 1967). It is interesting that the metabolite $\mathrm{N}$-acetylprocainamide bears a structural resemblance to practolol (Davies et al., 1975). Our findings show that 2 out of 19 patients on practolol and 1 out of 16 on labetalol, with no clinical adverse reactions, had high titres of ANA with normal levels of anti-DNA antibody. However, one of the patients on practolol, with a high titre of ANA and later ICC antibody, developed sclerosing peritonitis over the following year.

Pemphigus (natural and drug-induced), burns, practolol toxicity, and long-term therapy are associated with high titres of ICC antibody (Anderson et al., 1970; Thivolet et al., 1970; Amos et al., 1975; Behan et al., 1976; Davies and Holt, 1976; Gange et al., 1976). We have found such high titres in 16 out of 20 patients with practolol-induced OMCS, as well as in 1 out of 19 and in 1 out of 5 patients on long-term therapy with practolol and tolamolol respectively.

The incidences of low titres of ANA and ICC antibody in all groups were within normal limits. No patients had the rheumatoid factor.

Estimation of tear secretion (by Schirmer's test) and estimation of ANA before and during therapy with some beta-blockers have been suggested as screening tests for adverse drug reaction (Felix et al., 1974; Richardson et al., 1975). We suggest that any patient who complains of a dry eye while on therapy with a beta-blocker, particularly a $\beta_{1^{-}}$ selective blocker, should be examined by an ophthalmologist and the tear lysozyme ratio be estimated on three occasions. If this ratio oscillates to less than 0.9 , it is significantly reduced and is suggestive of impaired lachrymal gland function. Although expert ophthalmological examination will usually show if any abnormality exists, it is not always available; furthermore, the tear lysozyme ratio may be low before clinical signs of adverse ocular reaction appear. Although the mechanism of adverse reaction to beta-blockers is obscure, it seems advisable to test all patients on beta-blockers for ANA and ICC antibody, since high titres may occur before clinical signs of an adverse drug reaction appear.

We are greatly indebted to $\mathrm{Mr}$ Peter Wright (Moorfields Eye Hospital, London). We also thank Dr P. J. Richardson (King's College Hospital, London); Dr C. Chapman (Moorfields Eye Hospital); Dr D. Fleck, Dr N. Robinson, and $\mathrm{Mr}$ J. Oragui (St George's Hospital, London); Dr J. Kane 
(Kingston-upon-Thames); the Medical Divisions of Imperial Chemical Industries, Merck, Sharpe, \& Dohme, and Allen \& Hanburys; and St George's Hospital research fund (grant QK 351) for assistance. We also thank Professor J. Milne (University of Glasgow Dermatology Department), and Mrs P. Hilson (St Helier Hospital) for performing ICC antibody and ANA tests respectively.

\section{References}

Adler, F. H. (1970). Physiology of the Eye, 5th ed., rev. R. A. Moses. Mosby: USA.

Amos, H. F., Brigden, W. D., and McKerron, R. A. (1975). British Medical Journal, 1, 598.

Anderson, H. J., Newcomer, V. D., Landau, J. W., and Rosenthal, L. H. (1970). Archives of Dermatology, 101, 538.

Behan, P. O., Behan, W. M. H., Zacharias, F. J., and Nicholls, J. T. (1976). Lancet, $2,984$.

Bijsterveld, O. P. van (1973). Ophthalmologica, 167, 429.

Clayden, J. R. (1975). British Medical Journal, 2, 557.

Cubey, R. B., and Taylor, S. H. (1975). British Medical Journal, 4, 328.

Cumberbatch, J. B. (1974). British Medical Journal, 4, 528.

Davies, D. M., Beedie, M. A., and Rawlins, M. D. (1975). British Medical Journal, 3, 682.

Davies, M. G., and Holt, P. (1976). Archives of Dermatology, 112, 1308.

Duke-Elder, S. (1968). System of Ophthalmology, Vol. 4, The Physiology of the Eye and Vision. Kimpton: London. Editorial (1975). British Medical Journal, 2, 577.
Erickson, O. F. (1955). Stanford Medical Bulletin, 13, 292.

Fakhro, A. M., Ritchie, R. F., and Lown, B. (1967). American Journal of Cardiology, 20, 367.

Felix, R. H., Ive, F. A., and Dahl, M. G. C. (1974). British Medical Journal, 4, 321.

Gange, R. W., Rhodes, E. L., Edwards, C. O., and Powell, M. E. A. (1976). British Journal of Dermatology, 95, 445.

Holt, P. J. A., and Waddington, E. (1975). British Medical Journal, 2, 539 .

Hughes, G. R. V. (1971). Lancet, 2, 861.

Knapp, M. S., and Galloway, N. R. (1975). British Medical Journal, 2, 557.

Mackie, I. A., and Seal, D. V. (1975). British Medical Journal, 4, 732 .

Mackie, I. A., and Seal, D. V. (1976). British Journal of Ophthalmology, 60, 70.

Maes, J. (1938). American Journal of Physiology, 123, 349.

McEwen, W. K., and Kimura, S. J. (1955). American Journal of Ophthalmology, 39, 200.

Padfield, P. L., Beevers, D. G., Cochran, R., and McQueen, A. (1975). British Medical Journal, 1, 626.

Pinschmidt, N. W. (1970). Southern Medical Journal, 63, 1256.

Raftery, E. B., and Denman, A. M. (1973). British Medical Journal, 2, 452.

Raftery, E. B. (1974). British Medical Journal, 4, 653.

Rahi, A. H. S., Chapman, C. M., Garner, A., and Wright, P. (1976). British Journal of Ophthalmology, 60, 312.

Richardson, P. J., Tee, D. E. H., and Oram, S. (1975). British Medical Journal, 4, 648.

Thivolet, J., Beyvin, A., and André, D. (1970). Dermatologica, 140, 310.

Wright, P. (1975). British Medical Journal, 1, 595.

Wright, P. (1975). British Medical Journal, 4, 577. 